\title{
Institutional Delivery Among Young Women in Ethiopia: Further Analysis of Trends and Determinants, from the Four Consecutive Ethiopia Demographic and Health Survey
}

This article was published in the following Dove Press journal:

International Journal of Women's Health

\author{
Alemi Olika Kebede' \\ Yonas Terfa Biratu (D) ${ }^{2}$ \\ Ayantu Olika Kebede ${ }^{3}$ \\ Sena Kitila Belina (D) $^{2}$ \\ 'Population and Family Health \\ Department, Jimma University Institute \\ of Health Science, Jimma, Ethiopia; \\ ${ }^{2}$ School of Nursing and Midwifery, Jimma \\ University Institute of Health Science, \\ Jimma, Ethiopia; ${ }^{3}$ Department of \\ Epidemiology, Jimma University Institute \\ of Health, Jimma, Ethiopia
}

Purpose: Although young people have a right to sexual and reproductive health, they are facing inadequate access to information and services. The Ethiopian government has started implementing policies and strategies to eliminate inequalities in reproductive health service use. However, there are huge disparities in institutional delivery utilization between different age groups. Therefore, this study aimed to explore trends and factors associated with institutional childbirth among young women in Ethiopia.

Methods: Ethiopian demographic and health survey data (EDHS) from 2000 to 2016 surveys were used. Data on the most recent births to women aged 15-24 years that occurred in the 5 years preceding the survey period were extracted. All the four EDHS data were used to examine trends of institutional delivery, whereas determinants for institutional delivery were analyzed from a 2016 dataset by using multivariable logistic regression analysis.

Findings: Between 2000 and 2016, the proportion of institutional delivery among young women increased from $6 \%(95 \% \mathrm{CI}=3.7-6.5 \%)$ to $40.1 \%(95 \% \mathrm{CI}=30.6-44.3 \%)$. The odds of institutional delivery increased for young women who had attended secondary and above education $(\mathrm{AOR}=2.68 ; 95 \% \mathrm{CI}=1.559-4.607)$, started $\mathrm{ANC}$ visits early $(\mathrm{AOR}=1.518 ; 95 \%$ $\mathrm{CI}=1.095-2.105)$ and received four or more $\mathrm{ANC}$ visits $(\mathrm{AOR}=1.87 ; 95 \% \mathrm{CI}=1.370-2.561)$. However, the odds were lower among young women who had two (AOR $=0.31 ; 95 \%$ $\mathrm{CI}=0.185-0.514)$, and three or more children $(\mathrm{AOR}=0.62 ; 95 \% \mathrm{CI}=0.452-0.849)$.

Conclusion: There is an increase in trend of institutional delivery among young women during the 2000 to 2016 EDHS. Having higher educational levels, early ANC booking, and attending four or more ANC visits were positively associated with institutional delivery. Increased number of children is negatively associated with institutional delivery. Strengthening strategies for improving girls' education and addressing their socioeconomic and demographic vulnerabilities, and strengthening strategies being implemented for encouraging early and recommended ANC visits is crucial.

Keywords: young, youth, institutional delivery, factors, EDHS, Ethiopia

\section{Introduction}

Globally, around one in every six people are youth aged 15-24 years, and SubSaharan Africa countries are home to 211 million youths. ${ }^{1}$ Similarly, individuals in the age range of 15-29 years compromise more than $28 \%$ in Ethiopia. ${ }^{2}$ These young populations are a substantial group of the population that faces emotional and physical health challenges. For instance, young women are at higher risk to die
Correspondence: Alemi Olika Kebede Tel +251 910017441

Email alemikebede@gmail.com
International Journal of Women's Health 2020:12 1047-1056

1047 
from complications related to childbirth across the world, with the largest burden in developing countries. ${ }^{3-5}$ Giving birth at a health facility plays a critical role in averting the complications related to the birth and improve maternal and neonatal outcomes. ${ }^{6-11}$ However, in Ethiopia, young women give birth at home without assistance from skilled personnel. $^{12}$

The Ethiopian government is implementing policies and strategies to support young people and increase their access to sexual and reproductive health services. ${ }^{13-15}$ However, still young people are facing a number of health challenges, including inadequate access to sexual and reproductive health information and services. ${ }^{16,17}$ Despite the available literature on factors that hinder reproductive age women from utilizing institutional delivery, so far, no study has explicitly focused on young women's trends in the use of institutional delivery and associated factors in Ethiopia. Hence, this broader range of data, collected at a national level and for specific age groups, is important to examine the factors.

Thus, to meet the sexual and reproductive health needs of young women, identifying the factors associated with institutional delivery should be better understood that would support health program managers and policymakers for strengthening policy and programs targeting young women in Ethiopia. Therefore, this study aimed to examine the trends and factors associated with use of institutional delivery among young women in Ethiopia using the Ethiopian demographic and health survey data.

\section{Materials and Methods}

The source of data for this study was the four consecutive years' (2000, 2005, 2011, and 2016) EDHS. This study used data on births which had occurred in the 5 years preceding the survey period, and was restricted to the most recent births to young women aged 15-24 years. In this study, 2,199, 2,010, 1,914, and 1,804 youths from each survey year were considered, irrespective of their marital status. All four EDHS data were used to examine trends of institutional delivery and delivery care assisted by skilled birth attendants, whereas determinants for institutional delivery were analyzed using the EDHS 2016 data set.

Institutional delivery was a dependent variable in this study. It was categorized into "yes", when the birth took place at any private and public health facilities, and "no", when the birth took place at home. The independent variables include: respondent and husband's education and occupation, household wealth index, place of residence, age of respondent, number of living children, timing and frequency of the ANC, status of last pregnancy, listening to the radio, watching TV, and reading newspaper/magazines (Table 1)

Statistical analyses were performed using SPSS version 21. Standard EDHS sample weight was applied to account for the unequal probability of selection in the sample and nonresponse prior to any statistical analysis. The recommended procedure on how to weight DHS data in SPSS was followed. The weighting variables used was women's individual sample weight, since the study unit of analysis is women.

Descriptive analysis was used to describe socio-demographic and other variables of the study participants. Binary logistic regression analysis was done for selecting of candidate variables for the final model. A multivariable logistic regression analysis was carried out to determine the adjusted

Table I Description of Independent Variables

\begin{tabular}{|c|c|}
\hline \multicolumn{2}{|c|}{ Variable Description } \\
\hline $\begin{array}{l}\text { Educational } \\
\text { status }\end{array}$ & $\begin{array}{l}\text { Recoded into no formal education, primary, and } \\
\text { secondary and above, by combining secondary } \\
\text { and higher. }\end{array}$ \\
\hline $\begin{array}{l}\text { Maternal } \\
\text { Occupation }\end{array}$ & $\begin{array}{l}\text { Re-coded as not working, agriculture, sales, and } \\
\text { others. } \\
\text { Other is formed by combining professional/ } \\
\text { managerial, skilled and unskilled manual, clerical, } \\
\text { and services, due to the small number of cases } \\
\text { per each category }\end{array}$ \\
\hline $\begin{array}{l}\text { Husband } \\
\text { Occupation }\end{array}$ & $\begin{array}{l}\text { Recoded into not working, agriculture, sales, } \\
\text { skilled manual. professional/technician, unskilled } \\
\text { manual and others (by combining clerical, } \\
\text { services), and do not know }\end{array}$ \\
\hline Wealth index & $\begin{array}{l}\text { Recoded as poor, middle, and rich by combining } \\
\text { "poorer" and "poor" for poor and "rich" and } \\
\text { "richer" for rich }\end{array}$ \\
\hline $\begin{array}{l}\text { Timing of first } \\
\text { ANC visit }\end{array}$ & $\begin{array}{l}\text { Recoded as early when ANC visit occurred } \\
\text { during the first trimester, late when the first visit } \\
\text { took place during the second and third trimester } \\
\text { and do not know }\end{array}$ \\
\hline $\begin{array}{l}\text { Frequency of } \\
\text { ANC visit }\end{array}$ & $\begin{array}{l}\text { Recoded as less than four visits, four or above, } \\
\text { and do not know }\end{array}$ \\
\hline $\begin{array}{l}\text { Status of last } \\
\text { birth }\end{array}$ & $\begin{array}{l}\text { Recoded to unintended by combining wanted no } \\
\text { more and wanted later/miss time, and intended if } \\
\text { a young woman reported the last pregnancy was } \\
\text { wanted }\end{array}$ \\
\hline
\end{tabular}

Abbreviation: ANC, antenatal care. 
effect of selected candidate factors on the dependent variable. Multicollinearity was checked using variance inflation factor, and the maximum value of variance inflation factor was three. The results of the logistic regression analysis were presented by using adjusted OR with $95 \%$ CI.

Permission to access the data was given by the demographic and health surveys program. Then the data was accessed from the DHS program official database. The datasets were treated with utmost confidentially. All figures and tables in the report depict weighted numbers and percentages.

\section{Results}

\section{Trend in Institutional Delivery}

The data indicate that institutional delivery has been steadily improving over the last decades. The percentage of young mothers who gave birth at the health institution increased by more than 6-fold during the years 2000 to 2016. Institutional delivery improved from $6 \%(95 \% \mathrm{CI}=3.7-6.5 \%)$ recorded in the year 2000 , to $8.1 \%(95 \% \mathrm{CI}=6.1-8.5 \%)$ in 2005 , to $15.2 \%(95 \% \mathrm{CI}=13.1-16.3 \%)$ in 2011 , and $40.1 \%(95 \%$ $\mathrm{CI}=30.6-44.3 \%)$ in the year 2016. The proportion of improvement varies across the survey years. Between the 2000 and 2011 surveys, it increased by $9.2 \%$. The highest proportion is observed between 2011 and 2016 survey years, it more than doubled. The Cochran Mantel Haenszel test was done to see whether there is a significant change in institutional delivery over the past decades, and a significant change was observed $(P$-value $<0.001)$. Similarly, delivery care assisted by healthcare professionals has shown a continuous improvement of nearly $7 \%$ in the 2000 survey, to $9.2 \%$ in the 2005 survey, $16.4 \%$ in the 2011 survey, and $41.3 \%$ in the 2016 survey (Figure 1).

The proportion of institutional delivery varies significantly with age, place of residence, educational attainment, and household wealth status. In all four surveys, use of health facility for childbirth was more common among young women in urban areas, in the highest wealth status and with a higher educational level. Institutional delivery increases more than 4- and 7-fold between 2000 and 2016 among young women at age 15-19 years and 20-24 years, respectively. Although there is continuous improvement on institutional delivery in general, only $21.2,27.1$, and $34.7 \%$ of young women had not attended formal education, were from a poor household wealth status, and living in a rural area, respectively, gave birth at a health facility according to 2016 survey year (Table 2).

\section{Characteristics of the Respondents}

A total of 1,804 women aged 15-24 years who gave birth at least once in the last 5 years before EDHS 2016 were included in the analysis. Most (90\%) of the respondents were from rural areas; almost half (49.7\%) had primary education, and only $2.7 \%$ of the respondents and $18.4 \%$ of their husbands had attended secondary or above educational level. More than

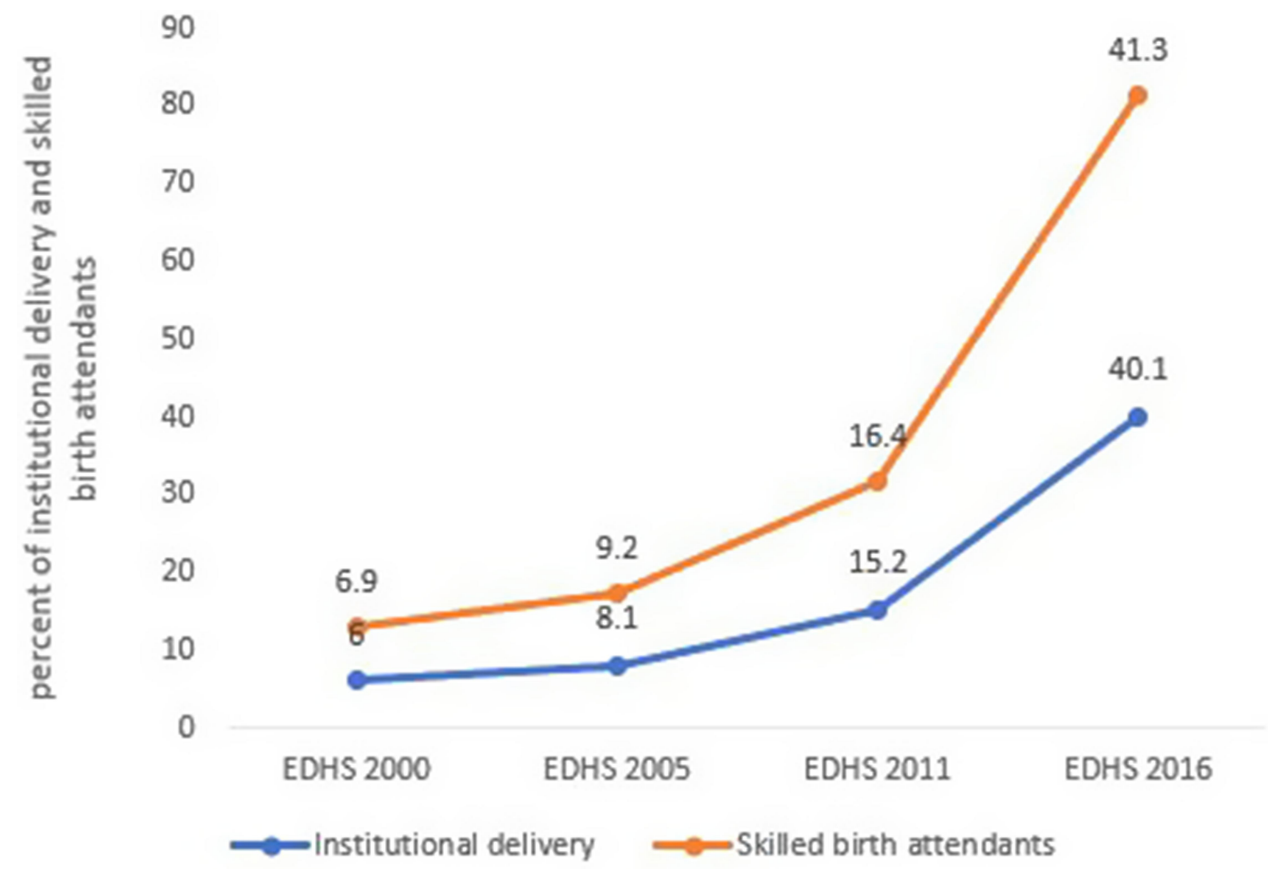

Figure I Trends in institutional delivery and delivery assistance from healthcare professionals in Ethiopia, 2000-2016. 
Table 2 Distribution of Young Women Who Utilized Institutional Delivery by Demographic and Socioeconomic Characteristics for Each Survey Year

\begin{tabular}{|c|c|c|c|c|}
\hline Young Women's Characteristics & Year $2000(N=2,199)$ & Year $2005(\mathrm{~N}=2,010)$ & Year $20 I I(N=I, 9 \mid 4)$ & Year $2016(N=I, 804)$ \\
\hline \multicolumn{5}{|l|}{ Age group } \\
\hline $15-19$ & 9.3 & 5.7 & 10 & 41.2 \\
\hline $20-24$ & 5.1 & 8.9 & 16.5 & 39.8 \\
\hline \multicolumn{5}{|l|}{ Place of residence } \\
\hline Urban & 34.4 & 46.9 & 58.5 & 88.3 \\
\hline Rural & 2.1 & 3.7 & 7 & 34.7 \\
\hline \multicolumn{5}{|l|}{ Education of respondents } \\
\hline No education & 2.6 & 3.8 & 5.3 & 21.2 \\
\hline Primary & 10.8 & 11.6 & 19.9 & 45 \\
\hline Secondary and above & 37.5 & 50.9 & 59.7 & 82.5 \\
\hline \multicolumn{5}{|l|}{ Husband education } \\
\hline No education & 1.4 & 3.3 & 5.7 & 26 \\
\hline Primary & 5.0 & 6.3 & 13.5 & 36.7 \\
\hline Secondary and above & 22.8 & 30.8 & 48.3 & 73.1 \\
\hline \multicolumn{5}{|l|}{ Wealth status } \\
\hline Poor & NA & 2 & 4.2 & 27.1 \\
\hline Middle & NA & 2.3 & 6.3 & 36.4 \\
\hline Rich & NA & 18.8 & 33.2 & 61.6 \\
\hline \multicolumn{5}{|l|}{ Marital status } \\
\hline Never married & 37.1 & 18.5 & 30.8 & 73.5 \\
\hline Married & 5.1 & 7.6 & 14.7 & 39.8 \\
\hline Divorced/separated & 9.3 & 6.9 & 19.3 & 37.8 \\
\hline
\end{tabular}

two fifths $(45.6 \%)$ of young women were from Oromia regional state. With regard to Religious affiliation, about $41.9 \%$ and $39.9 \%$ were Muslim and Orthodox, respectively.

Most of the young women were in a marital union, while $7.1 \%$ were divorced/separated, and only nearly $2 \%$ were never married. About one fifth of the participants were adolescent girls in the age range of 15-19 years. This finding indicated the practice of early marriage and early sexual activities. Although it is illegal in Ethiopia, still girls were engaging in early marriage. Early marriage has a negative consequence on the economic development of nations, in addition to causing a significant health risk to both the girl and her baby. ${ }^{18}$ Regarding their economic status, $47.8 \%$ of the young women fell into the poor socio-economic category. The majority $(1,130,62.6 \%)$ of the respondents were not working at the time of the survey, and 1,027 (56.9\%) of the husband's work was based on agriculture (Table 3 ).

\section{Obstetric and Related Factors}

More than one in five of the last births among young women were unintended births, and nearly three fifths $(57.7 \%)$ of the young women had one child. Slightly more than two thirds $(68.5 \%)$ had gotten some prenatal care from skilled providers. Among young women who gave birth in the last 5 years before the 2016 EDHS survey, only one third (32.6\%) of the young women received their first ANC visit within the first trimester of pregnancy, and less than half (45.1\%) of them attended four or more ANC during their pregnancy (Table 4).

According to the finding from this analysis, nearly two thirds of the young women who had four or more ANC visits, and more than three fifths of these women who started the visit early gave birth at the health facility. Institutional delivery increases nearly 4-fold from $12.4 \%$ to $48.3 \%$, and more than six-fold (6.5\% to $41.9 \%)$ between 2000 to 2016 among young women who started ANC late and had less than four ANC visits, respectively (Figure 2).

\section{Factors Associated with Institutional} Delivery Among Young Women in Ethiopia Table 5 shows unadjusted and adjusted ORs for institutional delivery among young women in Ethiopia for selected 
Table 3 Distribution of the Young Women Who Give Birth in the Last 5 Years Before EDHS 2016 by Their Background Characteristics

\begin{tabular}{|c|c|c|c|}
\hline Variable & Category & $\begin{array}{l}\text { Frequency } \\
(\mathrm{N}=1,804)\end{array}$ & Percent \\
\hline Age & $\begin{array}{l}15-19 \\
20-24\end{array}$ & $\begin{array}{l}339 \\
1,465\end{array}$ & $\begin{array}{l}18.8 \\
81.2\end{array}$ \\
\hline $\begin{array}{l}\text { Place of } \\
\text { residence }\end{array}$ & $\begin{array}{l}\text { Urban } \\
\text { Rural }\end{array}$ & $\begin{array}{l}181 \\
1,623\end{array}$ & $\begin{array}{l}10.0 \\
90.0\end{array}$ \\
\hline Education & $\begin{array}{l}\text { No education } \\
\text { Primary } \\
\text { Secondary and } \\
\text { above }\end{array}$ & $\begin{array}{l}701 \\
895 \\
208\end{array}$ & $\begin{array}{l}38.9 \\
49.6 \\
11.5\end{array}$ \\
\hline Marital status & $\begin{array}{l}\text { Never married } \\
\text { Married } \\
\text { Divorced/ } \\
\text { separated } \\
\text { Widowed }\end{array}$ & $\begin{array}{l}34 \\
1,634 \\
127 \\
9\end{array}$ & $\begin{array}{l}1.9 \\
90.6 \\
7.1 \\
0.5\end{array}$ \\
\hline Wealth index & $\begin{array}{l}\text { Poor } \\
\text { Middle } \\
\text { Rich }\end{array}$ & $\begin{array}{l}861 \\
368 \\
574\end{array}$ & $\begin{array}{l}47.8 \\
20.4 \\
31.8\end{array}$ \\
\hline Religion & $\begin{array}{l}\text { Muslim } \\
\text { Orthodox } \\
\text { Christian } \\
\text { Other Christian } \\
\text { Other }\end{array}$ & $\begin{array}{l}722 \\
634 \\
399 \\
49\end{array}$ & $\begin{array}{l}40.0 \\
35.2 \\
\\
22.1 \\
2.7\end{array}$ \\
\hline $\begin{array}{l}\text { Respondent } \\
\text { occupation }\end{array}$ & $\begin{array}{l}\text { Not working } \\
\text { Agriculture } \\
\text { Sales } \\
\text { Others* }\end{array}$ & $\begin{array}{l}1,130 \\
326 \\
177 \\
171\end{array}$ & $\begin{array}{l}62.6 \\
18.1 \\
9.8 \\
9.5\end{array}$ \\
\hline $\begin{array}{l}\text { Husband } \\
\text { Occupation }\end{array}$ & $\begin{array}{l}\text { Not working } \\
\text { Agriculture } \\
\text { Sales } \\
\text { Skilled manual } \\
\text { Professional/ } \\
\text { technician } \\
\text { Unskilled } \\
\text { manual } \\
\text { Others** }\end{array}$ & $\begin{array}{l}105 \\
1,027 \\
147 \\
101 \\
68 \\
50 \\
119\end{array}$ & $\begin{array}{l}5.8 \\
56.9 \\
8.1 \\
5.6 \\
3.8 \\
\\
2.8 \\
16.1\end{array}$ \\
\hline $\begin{array}{l}\text { Husband } \\
\text { education }\end{array}$ & $\begin{array}{l}\text { Do not know } \\
\text { No education } \\
\text { Primary } \\
\text { Secondary and } \\
\text { above } \\
\text { Do not know }\end{array}$ & $\begin{array}{l}16 \\
567 \\
756 \\
302 \\
9\end{array}$ & $\begin{array}{l}0.9 \\
34.7 \\
46.3 \\
18.4 \\
\\
0.5\end{array}$ \\
\hline Region & $\begin{array}{l}\text { OromiaHarari } \\
\text { Amhara } \\
\text { SNNPR }\end{array}$ & $\begin{array}{l}824 \\
334 \\
322\end{array}$ & $\begin{array}{l}45.6 \\
18.5 \\
17.8\end{array}$ \\
\hline
\end{tabular}

(Continued)
Table 3 (Continued).

\begin{tabular}{|l|l|l|l|}
\hline Variable & Category & $\begin{array}{l}\text { Frequency } \\
(\mathbf{N}=1,804)\end{array}$ & Percent \\
\hline & Tigray & 158 & 8.8 \\
& Somali & 67 & 3.7 \\
& Addis Adaba & 31 & 1.7 \\
& Afar & 25 & 1.4 \\
& Benishangul & 24 & 1.3 \\
& Dire Dawa & 9 & 0.5 \\
& Gambela & 6 & 0.3 \\
& Harari & 6 & 0.3 \\
\hline
\end{tabular}

Notes: Others*: professional/managerial, skilled and unskilled manual, clerical and services. Others**: clerical, services.

Abbreviations: SNNPR, Southern Nations, Nationalities, and People's Region; EDHS, Ethiopian demographic and health survey; DHS, demographic and health survey.

Table 4 Distribution of the Women Who Give Birth in the Last 5 Years Before EDHS 2016 by Their Obstetric and Related Characteristics

\begin{tabular}{|c|c|c|c|}
\hline Variables & Category & Frequency & Percent \\
\hline Status of last Birth & $\begin{array}{l}\text { Intended } \\
\text { Unintended }\end{array}$ & $\begin{array}{l}1,399 \\
405\end{array}$ & $\begin{array}{l}77.6 \\
22.4\end{array}$ \\
\hline $\begin{array}{l}\text { Number of living } \\
\text { children }\end{array}$ & $\begin{array}{l}\text { No child } \\
\text { One child } \\
\text { Two children } \\
\text { Three or more }\end{array}$ & $\begin{array}{l}31 \\
1,042 \\
496 \\
235\end{array}$ & $\begin{array}{l}1.7 \\
57.7 \\
27.5 \\
13.0\end{array}$ \\
\hline Prenatal care & $\begin{array}{l}\text { Yes } \\
\text { No }\end{array}$ & $\begin{array}{l}1,236 \\
568\end{array}$ & $\begin{array}{l}68.5 \\
31.5\end{array}$ \\
\hline $\begin{array}{l}\text { Timing of first } \\
\text { antenatal care }\end{array}$ & $\begin{array}{l}\text { Late } \\
\text { Early } \\
\text { Do not know }\end{array}$ & $\begin{array}{l}822 \\
403 \\
11\end{array}$ & $\begin{array}{l}66.2 \\
32.9 \\
0.9\end{array}$ \\
\hline $\begin{array}{l}\text { Frequency of antenatal } \\
\text { care }\end{array}$ & $\begin{array}{l}\text { Less than four } \\
\text { visits } \\
\text { Four or more } \\
\text { visits } \\
\text { Do not know }\end{array}$ & $\begin{array}{l}674 \\
558 \\
4\end{array}$ & $\begin{array}{l}54.6 \\
45.1 \\
0.3\end{array}$ \\
\hline
\end{tabular}

characteristics. In the binary logistic regression, the respondent's and their partner's education and occupation, frequency of exposure to media (reading magazines, listening to the radio, watching TV), wealth index, number of living children, prenatal care from skilled providers, timing and frequency of ANC visit, and place of residence emerge as significant factors influencing institutional delivery among young women in Ethiopia. Age of respondent, status of last birth, and decision-maker for the respondent's health did not have significant associations with the outcome variable in the 


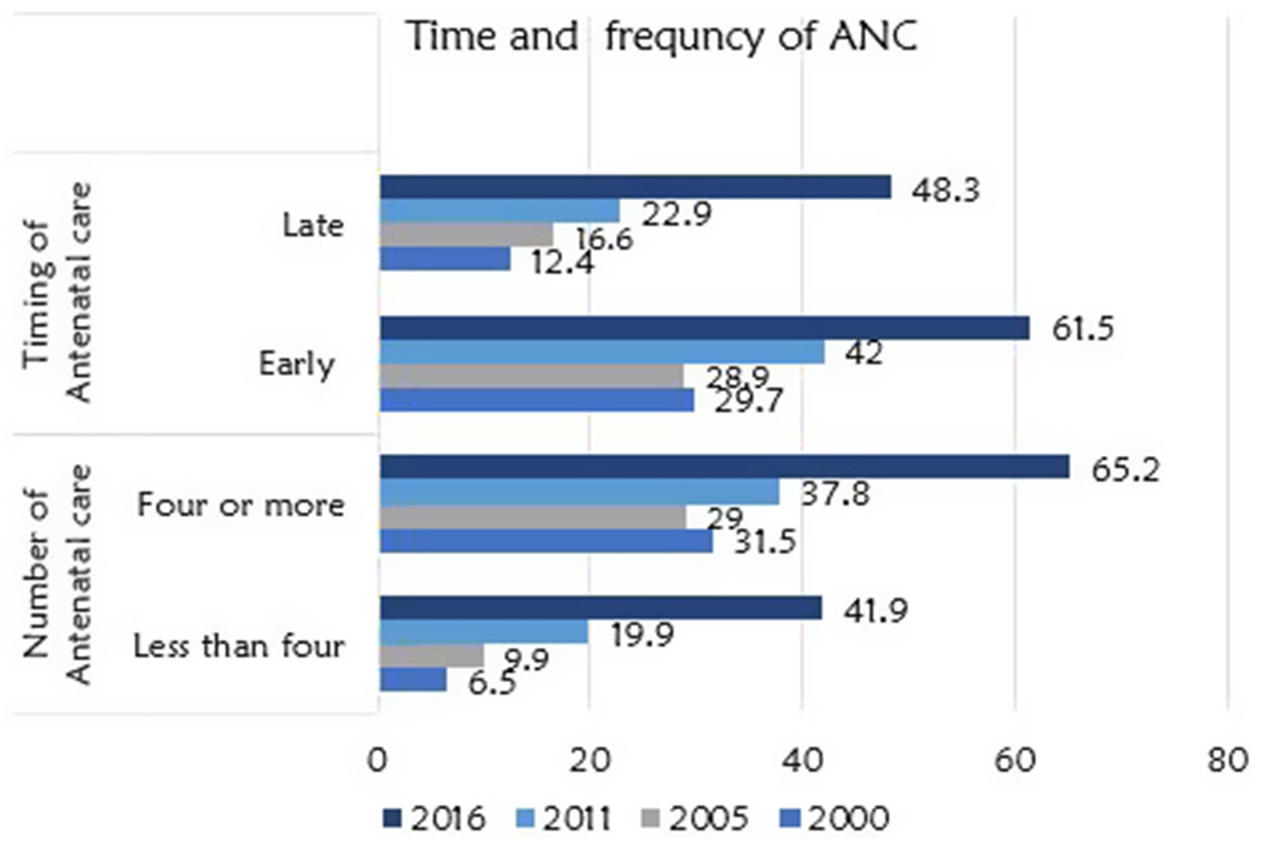

Figure 2 Institutional delivery by timing of first antenatal care and frequency of antenatal care among young women, Ethiopia DHS $2000-2016$.

binary regression; as a result they were excluded from the multivariable regression. All other remaining variables with a significant binary association were retained in the multivariable model. In the multivariable logistic number of living children, place of residence, wealth index, husband's and respondent's education, number and timing of ANC visit, and respondent's occupation continue to show a significant association with institutional delivery among young women.

Young women who had attended secondary and/or above level of education were 2.68-times more likely to have an institutional delivery compared with young women who attended primary education $(\mathrm{AOR}=2.68$; 95\% CI $=1.559-4.607)$. Also, the odds of using a health institution for childbirth compared to not using among young women whose husband attended secondary and above educational level were more than 2-time higher (AOR $=2.31 ; 95 \% \mathrm{CI}=1.516-3.521)$ compared to women whose husbands had only primary education.

Those in the higher economy were 1.6-times more likely to give birth at the health institution compared with young women from a lower economic status (AOR $=1.56 ; 95 \% \mathrm{CI}=1.094-2.214$ ). Regarding occupational status, young women participating in jobs such as skilled and unskilled manual, clerical, and technician were $56 \%$ less likely to utilize institutional delivery (AOR $=0.44 ; 95 \% \mathrm{CI}=0.256-0.760)$ compared to women who were not working at the time of the survey.
Regarding the use of ANC, young women who had received four or more ANC visits were about 2-times (AOR $=1.87 ; 95 \% \mathrm{CI}=1.370-2.561)$ and those started ANC early were 1.5 -times (AOR $=1.518 ; 95 \% \mathrm{CI}=1.095$ 2.105) more likely to utilize institutional delivery compared with young women who had received less than four ANC visits and started the visit late, respectively. In addition, women having two children were 69\% (AOR $=0.31 ; 95 \% \mathrm{CI}=0.185-0.514)$ and those with three or more children were $38 \%$ (AOR $=0.62 ; 95 \% \mathrm{CI}=0.452-$ 0.849) less likely to give birth at the health institution compared with those with one child (Table 5).

\section{Discussion}

This study was conducted to assess the trend and determinants of institutional delivery among young women in Ethiopia using the four DHS surveys from 2000 to 2016.

This analysis indicated that the trend of institutional delivery and skilled birth attendants among young women have been steadily improving over the years. This may be contributed to strong political commitment of the government to skilled birth attendance. For instance, the government of Ethiopia trained and deployed health extension workers working at the grass root level and also established a health development army in the county. In addition, construction of the maternity waiting area might address the problem of the long distances that was the 
Table 5 Binary and Multivariable Logistic Regression Model Showing Predictors of Contraceptive Use Among Young Women Who Gave Birth in the Last 5 Years, 2016 EDHS

\begin{tabular}{|c|c|c|c|c|c|}
\hline \multicolumn{2}{|l|}{ Variable and its Category } & \multicolumn{2}{|c|}{ Institutional Delivery } & \multirow{3}{*}{$\begin{array}{l}\text { COR }(95 \% \mathrm{Cl}) \\
0.237(0.097-0.579)\end{array}$} & \multirow{3}{*}{$\begin{array}{l}\text { AOR }[95 \% \mathrm{CI}] \\
0.34(0.093-1.28 \mathrm{I})\end{array}$} \\
\hline & & \multirow{2}{*}{$\frac{\text { Yes }}{6}$} & \multirow{2}{*}{\begin{tabular}{|l} 
No \\
25
\end{tabular}} & & \\
\hline & No child & & & & \\
\hline Number of living children & $\begin{array}{l}\text { One child } \\
\text { Two children } \\
\text { Three or above }\end{array}$ & $\begin{array}{l}515 \\
151 \\
38\end{array}$ & $\begin{array}{l}505 \\
333 \\
195\end{array}$ & $\begin{array}{l}\text { I } \\
0.444(0.353-0.557) \\
0.190(0.131-0.274)\end{array}$ & $\begin{array}{l}\text { I } \\
0.62(0.452-0.849)^{*} \\
0.31(0.185-0.5 \mid 4)^{*}\end{array}$ \\
\hline Place of residence & $\begin{array}{l}\text { Urban } \\
\text { Rural }\end{array}$ & $\begin{array}{l}157 \\
552\end{array}$ & $\begin{array}{l}21 \\
1,037\end{array}$ & $\begin{array}{l}\mid 4.052(8.82 \mid-22.385) \\
\text { I }\end{array}$ & $\begin{array}{l}8.38\left(3.776-18.593^{*}\right. \\
I\end{array}$ \\
\hline Respondent occupation & $\begin{array}{l}\text { Not working } \\
\text { Agriculture } \\
\text { Sales } \\
\text { Others }\end{array}$ & $\begin{array}{l}440 \\
214 \\
91 \\
83\end{array}$ & $\begin{array}{l}671 \\
106 \\
81 \\
83\end{array}$ & $\begin{array}{l}\text { I } \\
0.755(0.58 I-0.981) \\
1.357(0.982-1.875) \\
1.529(1.103-2.119)\end{array}$ & $\begin{array}{l}\text { I } \\
\text { I.24 (0.87I-I.774) } \\
\text { I.33(0.824-2.I5I) } \\
0.44(0.256-0.760) *\end{array}$ \\
\hline Number of ANC & $\begin{array}{l}\text { Four or more visits } \\
\text { Less than four visits }\end{array}$ & $\begin{array}{l}354 \\
278\end{array}$ & $\begin{array}{l}189 \\
386\end{array}$ & $\begin{array}{l}2.595(2.053-3.28 I) \\
\mathrm{I}\end{array}$ & $\begin{array}{l}\mathrm{I} .87(1.37-02.56 \mathrm{I})^{*} \\
\mathrm{I}\end{array}$ \\
\hline Timing of Ist ANC & $\begin{array}{l}\text { Early } \\
\text { Late }\end{array}$ & $\begin{array}{l}243 \\
390\end{array}$ & $\begin{array}{l}152 \\
418\end{array}$ & $\begin{array}{l}1.720(1.346-2.198) \\
1\end{array}$ & $\begin{array}{l}1.52(1.095-2.105)^{*} \\
\mathrm{I}\end{array}$ \\
\hline Husband education & $\begin{array}{l}\text { No formal education } \\
\text { Primary } \\
\text { Secondary and higher }\end{array}$ & $\begin{array}{l}147 \\
269 \\
220\end{array}$ & $\begin{array}{l}418 \\
464 \\
81\end{array}$ & $\begin{array}{l}0.608(0.478-0.773) \\
\mathrm{I} \\
4.707(3.50 \mathrm{I}-6.328)\end{array}$ & $\begin{array}{l}0.81(0.587-1.114) \\
I \\
2.31(1.516-3.52 I)^{*}\end{array}$ \\
\hline Respondent education & $\begin{array}{l}\text { No formal education } \\
\text { Primary } \\
\text { Secondary and higher }\end{array}$ & $\begin{array}{l}145 \\
395 \\
170\end{array}$ & $\begin{array}{l}539 \\
483 \\
36\end{array}$ & $\begin{array}{l}0.330(0.263-0.413) \\
\mathrm{I} \\
5.703(3.893-8.355)\end{array}$ & $\begin{array}{l}0.74(0.53 \mathrm{I}-\mathrm{I} .029) \\
\mathrm{I} \\
2.68(1.559-4.607)^{*}\end{array}$ \\
\hline Wealth Index & $\begin{array}{l}\text { Poor } \\
\text { Average } \\
\text { Rich }\end{array}$ & $\begin{array}{l}228 \\
130 \\
352\end{array}$ & $\begin{array}{l}613 \\
227 \\
219\end{array}$ & $\begin{array}{l}1.549(1.190-2.017) \\
4.333(3.453-5.439)\end{array}$ & $\begin{array}{l}\text { I } \\
\text { I.06 (0.736-I.528) } \\
\text { I.56 (I.094-2.2I4)* }\end{array}$ \\
\hline
\end{tabular}

Notes: *Significant value at 0.05 .

Abbreviations: $\mathrm{AOR}$, adjusted odd ratio; $\mathrm{Cl}$, confidence interval; $\mathrm{COR}$, crude odd ratio; $\mathrm{ANC}$, antenatal care.

major deterrent factor for institutional delivery, especially for rural women. Further, there are a number of global and local partners and civil society organizations working on improving maternal health.

The national prevalence of institutional delivery among young women in 2016 was in line with a study conducted in Nigeria, where more than two thirds of young mothers aged 15-24 years gave birth at home. ${ }^{19}$ However, the finding was slightly lower than the result from Nepal, where the rate of institutional delivery among young married women was $46 \%{ }^{20}$ This difference may be contributing to differences in the health system structures of the two countries. In Nepal there was a cash incentive given to women who completed four ANC and to those who gave birth at a health facility to cover transportation costs. Also, health staff received an incentive for attending the health facility and home delivery. ${ }^{21}$
Further, it was slightly higher than a study conducted in rural districts of Wolaita and Dawro Zones, where 38\% delivered at the health facility. ${ }^{22}$ The possible explanation may be due to differences in the sample size and study participants. In the study conducted in Wolaita and Dawro Zones, only 957 mothers who gave birth in a year preceding the survey were included.

This study further revealed the relationship between institutional delivery and associated factors. Accordingly, young women who had secondary and/or above education, were from urban residential and rich socio-economic status, had a history of early ANC booking, attended four or more ANC visits, and whose husband attended secondary and above education were more likely to give birth at the health facility. This finding is consistent with what has been observed in studies conducted in Nepal, India, Colombia, Bangladesh, Zambia, Egypt, Kenya, Ghana, 
Nigeria, and Ethiopia, where the institutional delivery is determined by educational attainment of women, household wealth status, place of residence, and number of children. $^{20,-23-35}$

This finding was in line with a study from Nigeria, where young women from a poor economic category had a higher prevalence of home delivery. ${ }^{19}$ Similarly, in Bangladesh, being part of the richest bands of wealth was associated with the use of skilled maternal health services among adolescents. ${ }^{36}$ Financial problems were one of the reasons women did not choose a health institution for childbirth. For instance, although the maternal health services are exempted, there are indirect costs such as transportation cost and some informal fees for some aspect of care, including drugs and supplies. Thus, this out of pocket payment in seeking such services could have made the uptake of these services difficult for the poorest segments of society. ${ }^{37}$

Higher educational attainment was also a significant predictor for childbirth at the health facility. This finding was consistent with evidence indicated in Colombia, Nepal, Bangladesh, Zambia, and Kenya. ${ }^{27,38}$ A study from Indonesia also indicated the same findings, women who have achieved higher levels of education were more likely to deliver at health facilities than those of lower educational status. ${ }^{39}$ This implies that women have better access to health information and awareness about the negative consequences of not using skilled delivery care if they are educated. Also, the decision-making ability to use healthcare services increases with increased women's educational level.

Similarly, the educational status of the husband was directly associated with institutional delivery. This finding was consistent with a study in Nigeria that indicated higher odds of home delivery with a lower educational status of the husband. ${ }^{19}$ A study from Gambia also favors the direct relationship between a husband's higher educational status with institutional delivery. ${ }^{40}$ This could be due to the reason that the more the husband is educated, the more he would be aware of the benefits of institutional delivery, so that he encouraged his wife to give birth at the health facility. Also, most of the time educated husbands participated in the decision-making and were also more likely to accompany their wife to a health facility for childbirth.

Place of residence was also an independent factor significantly associated with institutional delivery. This is similar to other studies conducted in Bhutan, where women living in rural areas were more likely to deliver at home. ${ }^{27}$ Similar findings were observed in studies conducted in Nepal and some parts of Ethiopia. ${ }^{15,26,38,43}$ This could be due to the reason that urban women have several advantages compared with the rural women such as having higher levels of education, greater knowledge and awareness, and easy access to higher public and private healthcare facilities, whereas rural women are often in denial of these opportunities.

Booking time and frequency of antenatal care were also key predictors of the use of the health institution for childbirth in this study. Previous studies also highlighted antenatal care as a precursor for institutional delivery. For instance, finding from some primary studies and a systematic review and meta-analysis in sub-Saharan African countries indicated that mothers who attended at least four ANC visits were more likely to deliver in a health facility. ${ }^{25,27,30,38,41,42}$ The possible explanation might be as a result of the information they got during an ANC visit on the advantage of skilled care during delivery, young mothers decide to attend a health institution for childbirth. Antenatal care services ensure opportunities for women by which they receive the necessary information. Similarly, the World Health Organization (WHO) recommends that ANC should consist of at least four visits during the course of the pregnancy, the first of which should occur within the first trimester. Timing of first antenatal care is an important entry point for delivering care, as young women who initiated antenatal care early were more likely to use the health institution for childbirth. ${ }^{43}$

Further, the young women's working status is also a significant determinant for institutional delivery. According to this study, young women who were working as professional/managerial, skilled and unskilled manual, clerical and services were less likely to give birth in health facilities when compared with those who were not working. Although this is in contrast with previous studies in Tanzania and Ethiopia that identified working mothers were more likely to giving birth in health facilities, ${ }^{44,45}$ it was consistent with the finding from Indonesia. ${ }^{39}$ This could possibly be because, in some of the cases, mothers are head of household and breadwinner. Thus, missing work for the sake of visiting a health facility might cause a lack of food on the table in the household. Also, women may not have enough funds to give birth in a health facility beyond hand to mouth, in the sense that the income does not provide other services rather than food services for the family.

Moreover, this study has indicated that numbers of living children are also significant predictors of childbirth 
at the health facility. As the number of children increased; there is a lower possibility of using institutional delivery. This finding was consistent with previous studies in Ethiopia. $^{22,46}$ Also, it is similar with a study in Uttarakhand, India, where mothers of higher birth order were less likely to deliver with the attendance of skilled personnel as compared to lower birth order. ${ }^{47,48}$

This study has certain limitations. First, the cross-sectional nature of the data does not allow for drawing causal inferences. Second, DHS data are associated with recall bias given that data was collected retrospectively on events that took place 5 years before the survey. Moreover, this study does not explain any programmatic and sociocultural factors of the determinants of institutional delivery.

\section{Conclusion}

There is an increase in trend of institutional delivery among young women during the 2000 to 2016 EDHS, however still the majority of young women gave birth at home. Having higher educational levels for young women and their husband, being the richest in wealth, residing in urban areas, having four or more visits ANC, and starting the visit early were positively associated with use of institutional delivery. However, the number of children a woman has is inversely related to institutional delivery. Strengthening strategies for improving girls' education and addressing their socio-economic and demographic vulnerabilities will improve the use of institutional delivery. Therefore, investment in the education of young women and their husband is needed, and more attention should be given to rural young women. Also, strengthening strategies being implemented for encouraging the early and recommended four ANC visits are crucial.

In addition, the finding indicated the practice of early marriage given the available national adolescent and youth health strategies. Therefore, strategies should consider involving community members and youth representatives to tackle early marriage. Also, the motives and external pressure for early marriage should be elaborated on by further studies.

\section{Acknowledgments}

We would like to thank the Demographic and Health Surveys (DHS) Program for availing the data and for their commitment.

\section{Disclosure}

The authors do not have any conflicting interests to declare.

\section{References}

1. Nations U, Development S, Division P. International Youth Day, 12 August 2019 Ten key messages. 2019;2019-2020.

2. Fact Sheet USAID. Developing Ethiopia's Youth. Developing Ethiopia' S Youth. 2017:1-2.

3. United Nations Children's Fund (UNICEF). The State Of The World' $s$ children Maternal and Newborn Health where we stand; 2009.

4. Frost M, Fogstad H, A V C, Neal S, Zo E, Laski L. Childbearing in adolescents aged $12-15$ years in low resource countries: a neglected issue. New Estimates Demographic Household Sur 42 Countries. 2012;91:1114-1118.

5. The global Strategy For women's, Children's and Adolescents' Health Every women every child (2016-2030). 2016.

6. Karkee L, Binns CW, Lee AH, et al. Determinants of facility delivery after implementation of safer mother programme in Nepal: a prospective cohort study. BMC Pregnancy Childbirth. 2013;13(1):193. doi:10.1186/1471-2393-13-193

7. De BV, Richard F, Witter S. Access to maternal and perinatal health services: lessons from successful and less successful examples of improving access to safe delivery and care of the newborn. Tropical Med Int Health. 2010;15(8):901-909.

8. Mpembeni RNM, Killewo JZ, Leshabari MT, et al. BMC Pregnancy and Childbirth Use pattern of maternal health services and determinants of skilled care during delivery in Southern Tanzania: implications for achievement of MDG-5 targets. BMC pregnancy childbirth. 2007;7:1-7.

9. Central Statistical Agency (CSA) [Ethiopia] and ICF. Ethiopia Demographic and Health Survey 2016. Addis Ababa, Ethiopia, and Rockville, Maryland, USA: CSA and ICF; 2016.

10. Dean T. Jamison Rachel Nugent Hellen Gelband Susan Horton Prabhat Jha Ramanan Laxminarayan Charles N. Mock. Reproductive, Maternal, Newborn, and Child Health. DISEASE control priority Third edition. 2; 2016.

11. Campbell OMR, Graham WJ. Maternal Survival 2 Strategies for reducing maternal mortality: getting on with. Lancet. 2006;368.

12. https://www.oecd.org/dev/inclusivesocietiesanddevelopment/youthissues-in-ethiopia.htm.

13. Federal democratic Republic of Ethiopia Ministry of health. National Reproductive Health Strategy 2006-2015; 2006.

14. Federal democratic Republic of Ethiopia. Ministry of Youth, Sport and Culture. Ethiopian National Youth Policy; 2004.

15. Federal democratic Republic of Ethiopia. Ministry of Health. National Adolescent and Youth Health Strategy (2016-2020); 2016.

16. Kafle RB, Paudel R, Gartoulla P, MacQuarrie KLD. Youth health in Nepal: levels, trends, and determinants. DHS Furth Anal Rep. 2019;116:xvii.

17. Potter J, Trussell J, Moreau C. Trends and determinants of reproductive health service use among young women in the USA $\dagger$. Lancet. 2009;24(12):3010-3018.

18. Erulkar A. Adolescence lost: the realities of child marriage. J Adolesc Heal. 2013;52(5):513-514. (). doi:10.1016/j.jadohealth.2013.03.004

19. Adewuyi EO, Khanal V, Zhao Y, David L, Bamidele OD, Auta A. Home childbirth among young mothers aged $15-24$ years in Nigeria: a national population-based cross-sectional study. $B M J$ Open. 2019;9(9):e025494. doi:10.1136/bmjopen-2018-025494

20. Shahabuddin ASM, De BV, Adhikari R, Delamou A, Bardaj A, Delvaux T. Determinants of institutional delivery among young married women in Nepal. Evi Nepal Demographic Health Survey. 2017;2011. 
21. Factors S. Ministry of Health and Population Nepal, Partnership for Maternal, Newborn \& Child Health, WHO, World Bank and Alliance for Health Policy and Systems Research. Success factors for Women's and Children's Health. Nepal. Geneva: World Health Organisation; 2020.

22. Arba MA, Darebo TD, Koyira MM. Institutional Delivery Service Utilization among Women from Rural Districts of Wolaita and Dawro Zones, Southern Ethiopia; a Community Based Cross-Sectional Study. PloS one. 2016;1-10.

23. Tamang JP, Mcneil R, Tongkumchum P. Factors Associated with Non-Institutional Delivery among Pregnant Women in Nepal. Asian Soc Sci. 2019;15:7.

24. Paul P, Chouhan P. Socio-demographic factors in fl uencing utilization of maternal health care services in India. Clin Epidemiol Glob Heal. 2020;0-1.

25. Berhan Y, Berhan A. Review antenatal care as a means of increasing birth in the health facility and reducing maternal mortality: a systematic review. BMC Public Health. 6:93-104.

26. Tamang TM. Factors Associated with Completion of Continuum of Care for Maternal Health in Nepal. 2017;1-23.

27. Gurung MS, Pelzom D, Wangdi S, Tshomo T, Lethro P, Dema T. Factors Assoc Delivery Bhutan. 2018;7.

28. Hamed AF, Roshdy E, Sabry M. Egyptian status of continuum of care for maternal, newborn, and child health: Sohag Governorate as an example. J Med Sci Public Health. 2018;7(6):417-426.

29. Kikuchi K, Yasuoka J, Nanishi K, et al. Postnatal Care Could Be the Key to Improving the Continuum of Care in Maternal and Child Health in Ratanakiri. Cambodia; 2018:1-13.

30. Dahiru T, Oche OM. Determinants of antenatal care, institutional delivery and postnatal care services utilization in Nigeria. Pan African med $j .2016$.

31. Trujillo JC, Iglesias WJ. Relationship Between Professional Antenatal Care Facility Delivery. 2013;2016.

32. Akinyemi JO, Afolabi RF, Awolude OA. Patterns and determinants of dropout from maternity care continuum in Nigeria. BMC. 2016;1-11.

33. Mohan D, Lefevre AE, George A, et al. Analysis of dropout across the continuum of maternal health care in Tanzania: findings from a cross-sectional household survey. BMC J. 2017:791-9.

34. Shibanuma A, Yeji F, Okawa S, et al. The coverage of continuum of care in maternal, newborn and child health: a cross-sectional study of woman-child pairs in Ghana. BMJ global health. 2018;1-13.

35. Kasaye HK. Home delivery among antenatal care booked women in their last pregnancy and associated factors: community-based cross sectional study in Debremarkos town. 2017;1-12.
36. Review S. Utilization of maternal health services among adolescent women in Bangladesh: A scoping review of the literature *. J global health. 2015;20(7):822-829.

37. Pearson L, Gandhi M, Admasu K, Keyes Eb. International Journal of Gynecology and Obstetrics User fees and maternity services in Ethiopia. BMC pregnancy and childbirth. 2011;115:310-315.

38. Wang W, Hong R. Levels and determinants of continuum of care for maternal and newborn health in Cambodia- evidence from a population-based survey. BMC pregnancy and childbirth. 2015;1-9.

39. Efendi F, Rihlatun A, Hadisuyatmana S, Kuswanto H, Lindayani L, Berliana SM. Determinants of Facility-Based Childbirth in Indonesia. 2019;2019.

40. Yaya S, Bishwajit G. Predictors of institutional delivery service utilization among women of reproductive age in Gambia: a crosssectional analysis. BMC. 2020;4:1-10.

41. Health C, Paper W, Division P. Innovative Approaches to Maternal and Newborn Health Compendium of Case Studies. 2013.

42. Adjiwanou V, Social Science LT. Medicine Does antenatal care matter in the use of skilled birth attendance in rural Africa: A multi-country analysis. BMC. 2013;86:26-34.

43. Messages K, Recommendations G, Care RA. WHO. Recommendations on Antenatal Care for a Positive Pregnancy Experience: summary Highlights and Key Messages from the World Health Organization's 2016 Global Recommendations for Routine Antenatal Care. BMC J Dis. 2018;10:(January):1-10.

44. Ngowi AF, Kamazima SR, Kibusi S. Gesase A BTW's determinant factors for preferred place of delivery in $\mathrm{D}$ region $\mathrm{T}$ : a cross sectional study. 2017;1-8.

45. Fekadu GA, Omigbodun AO, Roberts OA, Yalew AW. Factors associated with long acting and permanent contraceptive methods use in Ethiopia. BMC Public Health. 2019;3:1-11.

46. Mehari AM. Levels and Determinants of Use of Institutional Delivery Care Services among Women of Childbearing Age in Ethiopia: analysis of EDHS 2000 and 2005 Data [WP83]. 2013.

47. Sahoo H. Factors influencing the Utilization of Maternal Health Care Services in Uttarakhand Factors influencing the Utilization of Maternal Health Care Services in Uttarakhand. 2017.

48. Sonneveldt E, Plosky WD, Stover J. Linking high parity and maternal and child mortality: what is the impact of lower health services coverage among higher order births? BMC Public Health. 2013;13 (Suppl 3):S7. (). doi:10.1186/1471-2458-13-S3-S7
International Journal of Women's Health

\section{Publish your work in this journal}

The International Journal of Women's Health is an international, peerreviewed open-access journal publishing original research, reports, editorials, reviews and commentaries on all aspects of women's healthcare including gynecology, obstetrics, and breast cancer. The manuscript management system is completely online and includes a very quick and fair peer-review system, which is all easy to use. Visit http://www.dovepress.com/testimonials.php to read real quotes from published authors. 